\title{
Reduction of Lead (Pb) with Na2 EDTA, Lime and Vinegar Acid in Fruit Processing Wheat Avicennia Marina
}

\author{
Titik Dwi Sulistiyati \\ Doctoral degree in Agriculture Faculty, Brawijaya University, Indonesia \\ Sudarminto Setyoyuwono \\ Agriculture Technology Faculty, Brawijaya University, Indonesia \\ Endang Yuli Herawati \\ Profesor in Fisheries and Marine Science Faculty, Brawijaya University, Indonesia \\ Sumarno \\ Profesor in Agriculture Faculty, Brawijaya University, Indonesia
}

Received: April 18, 2013 Accepted: May 22, 2013 Published: June 20, 2013

doi:10.5296/jfs.v2i1.3545～URL: http://dx.doi.org/10.5296/jfs.v2i1.3545

\begin{abstract}
Avicennia marina is a true mangrove species and is growing at the forefront of the zone system of mangrove plant growth. A. marina growing on land with a high saline stress the roots are always flooded. These plants bear fruit more than 3 times a year and the fruit can be used as food as long as it is properly processed to remove toxic materials. The research aims to find out how much the ability of some chelating agents to reduce the fruit Lead $(\mathrm{Pb})$ of the starch content $A$. marina so worthy as food for humans. The results showed that the fruit powder A. marina turned out to contain heavy metals lead $(\mathrm{Pb})$. The content of lead in the wheat $A$. marina fruit is reduced by a solution of lime, $\mathrm{Na}_{2}$ EDTA and it still meets the threshold maximum $\mathrm{Pb}$ content in the wheat based SNI 7387:2009 number ie $0.5 \mathrm{mg} \mathrm{kg}$. Given the extent of the spread of plant and higher fruit production A. marina, then use the fruit as a food starch can be developed. One important requirement is the use of starch production process must be well controlled in order to limit the maximum allowable $\mathrm{Pb}$ content in flour is not exceeded.
\end{abstract}

Keywords: Reduction, $\mathrm{Pb}, \mathrm{Na}_{2}$ EDTA, Vinegar acid, Avicennia marina 


\section{Introduction}

Mangroves grow on the land adjacent to the water reach the highest tide so the ecosystem is a transition region whose existence is also influenced by land and sea (Pramudji, 2001). Added by Bengen (2000), mangrove or mangrove ecosystems including marine coastal ecosystems or communities are found in shallow waters of the tropics and subtropics.

Mangrove ecosystem is a key chain as producers in the coastal ecosystem food webs. Besides mangrove ecosystems that have high productivity provide abundant food for many marine animals and provide breeding grounds, spawning, and rearing for several species of fish, shellfish, crabs and shrimp, thus indirectly human life depends on the presence of mangrove ecosystems. Mangrove also has a physical function for the shore as a coastal protection from waves and wind waves, retaining abrasion, rain water, preventing floods, and absorbent waste pollute the waters. Mangroves growing on the river end of the last act as a reservoir for waste from industrial and urban settlements are carried upstream watershed. Solid and liquid wastes are dissolved in the river water washed into estuaries and seas. Mangrove forest area will be an accumulation of waste, especially when pollutants that enter the estuarine environment beyond the capabilities of natural purification by water (Amin, 2001; Hamzah \& Setiawan, 2010). The main cause of heavy metal pollutants harmful to the heavy metals can not be destroyed (non degradable) by living organisms in the environment and accumulate to the environment, especially to the bottom waters to form complex compounds with organic and inorganic adsorption and combination (Arisandi, 2001). Aquatic biota living in heavy metal polluted waters, some heavy metals can accumulate in body tissues. The higher the metal content in the water the higher the content of heavy metal that accumulates in the body of the organism (shimoda et al., 1985).

The aim of reseach to knowing the effect of chelating agents such as $\mathrm{Na}_{2}$ EDTA, a solution of vinegar and lemon juice to the reduction of heavy metal $\mathrm{Pb}$ in Avicennia marina fruit.

The results in the form of information on the reduction of heavy metal $\mathrm{Pb}$ in Avicennia marina fruit flour processing using a chelating agent $\mathrm{Na}_{2}$ EDTA solution, a solution of lemon juice and vinegar.

\section{Materials and Methods}

Samples were obtained from coastal Osowilangun (Gresik district), Wonorejo (Surabaya district) and Bayeman (Probolinggo district).

\subsection{Sample preparations}

A. marina fruit initially separated between fruit peel, pulp and pistil. Part stigma causes a bitter taste. Parts used as flour is flesh. A. marina fruit crushed to facilitate the reduction of $\mathrm{Pb}$ metal. Fruit that is bruised boiled at a temperature of 80 to $90^{\circ} \mathrm{C}$ for 10 minutes. Boiling to obtain the desired texture and kill microbes. Draining done to reduce the water content after the boiling process. Having stewed fruit soaked absorbent concentration and immersion time are different for removing heavy metals contained in the flesh of the fruit. After soaking, the fruit is dried in a vacuum drying at a temperature of 60 to $700^{\circ} \mathrm{C}$ for $8-12$ hours until the moisture content of $4 \%$. The dried fruit was crushed using a blender until smooth. 


\section{Macrothink}

Journal of Food Studies ISSN 2166-1073 2013, Vol. 2, No. 1

Sieving performed using 60-80 mesh size sieve to separate the dirt and lint left in the fruit (Sudarmaj, et al 2003).

\subsection{Lead analysis}

$\mathrm{Pb}$ content analysis on raw materials and A. marina fruit powder test method Atomic Absorption Spectrometry (AAS). The principle of the analysis is the absorption of light by atoms. The atoms absorb light with certain wavelengths, depending on the nature of the elements (Lihan, et al., 2006).

\subsection{Atomic Absorption Spectrometry}

A. marina fruit flour results from each treatment were weighed 2 grams and put in a orcelain dish. Porcelain cup is inserted into the furnace to ashes at a temperature of $\pm 700^{\circ} \mathrm{C}$ for 2 hours, then cooled. Once cool add 5 cc of concentrated $\mathrm{HNO}_{3}$ and heated it up, then cooled again.Once cool add another 0.5 cc and 15 cc of concentrated $\mathrm{HNO}_{3}$ and then shaken with distilled water stir bar.Sample is slowly heated at a temperature of $120^{\circ} \mathrm{C}$ for $15 \mathrm{~min}$ and then cooled. Samples were filtered into a 100 cc flask and add distilled water to mark boundaries. AAS readings done by using the appropriate cathode lamp.

\section{Result and Discussion}

The analysis shows that all parts of the plant $A$. marina were present in all study sites turned out to contain Lead $(\mathrm{Pb})$. Content Lead is not only found in the roots, stems and leaves alone but are also present in the fruit as shown in Table 1.

Table 1. Detection of $\mathrm{Pb}$ content in the whole plant $A$. marina

\begin{tabular}{|l|c|c|c|}
\hline \multirow{2}{*}{ Remarks } & \multicolumn{3}{|c|}{ Contents Pb (ppm) } \\
\cline { 2 - 4 } & Osowilangun & Wonorejo & Bayeman \\
\hline Sedimen & 0.692 & 13.54 & 0.266 \\
\hline Water & 0.622 & 0.215 & 0064 \\
\hline Root & 0.692 & 1.660 & 0115 \\
\hline Tree skin & - & 2.860 & 0162 \\
\hline Leaf & & & 0.410 \\
\hline Bud leaf & 0.581 & 0.950 & 0.115 \\
\hline Leaf & 0.387 & & \\
\hline Fruit & & 1.330 & 0.165 \\
\hline Outer fruit & 0.387 & 1.660 & 0.132 \\
\hline Inner fruit & 0.277 & & \\
\hline
\end{tabular}

Source: Result of research analysis

A. marina fruit shaped grains have chemical components as a potential source of carbohydrates. This plant is widespread and can be found almost all over the coast, especially 
in areas that are Estuarine meeting between fresh water and sea water (river mouth).

Based on these facts, the content of $\mathrm{l}$ ead in A. marina can come from the water and nutrients in the soil where the growth is absorbed by the roots of a tree as the nourishment and spread throughout other parts of the tree.

Lead content in the presence of A. marina were observed very clearly caused by the environment which is the accumulation of pollutants from waters where industrial and household waste on land.

Table 1 shows that the higher the content of Lead in sediments is proportional to the height of lead on the roots and fruits of A. marina were observed. Based on the high content of lead, it is a region Wonorejo waters contaminated highest level. This area is an estuary of the times Surabaya which brings a lot of waste industrial and household waste from the city of Surabaya.

The extent of the area to grow plants A. marina on the coast is a great potential as a source for food substitution, as this tree can bear fruit almost throughout the year with peak fruit production could reach 3 times a year.

Flour is an alternative to the ideal processing techniques for utilization. In order A. marina fruit powder gives a high acceptance to the consumer, the maceration process is required to reduce unwanted chemical components, especially the content of lead. Maceration can use $\mathrm{Na}_{2}$ EDTA solution, a solution of lemon juice and vinegar solution in a concentration and time are some of the many alternative methods developed by the community in utilizing the fruits of A. marina.

Table 2 shows the ability of each $\mathrm{Na}_{2}$ EDTA solution, a solution of lemon juice and vinegar solution in reducing lead in $A$. marina fruit through a process of maceration.

Table 2. Results A. marina fruit maceration with some solution

\begin{tabular}{|l|c|c|c|c|c|c|}
\hline $\mathrm{Na}_{2}$ EDTA Solution & $\begin{array}{c}\mathrm{A} \\
(\mathrm{kontrol})\end{array}$ & $\begin{array}{c}\mathrm{B} \\
(0.9 \%)\end{array}$ & $\begin{array}{c}\mathrm{C} \\
(10 \%)\end{array}$ & $\begin{array}{c}\mathrm{D} \\
(11 \%)\end{array}$ & $\begin{array}{c}\mathrm{E} \\
(12 \%)\end{array}$ & $\begin{array}{c}\mathrm{F} \\
(1.3 \%)\end{array}$ \\
\hline Pb content (ppm) & 0.60 & 0.45 & 0.37 & 0.32 & 0.30 & 0.24 \\
\hline Lime Solution & $\begin{array}{c}\mathrm{A} \\
(\mathrm{kontrol})\end{array}$ & $\begin{array}{c}\mathrm{B} \\
(25 \%)\end{array}$ & $\begin{array}{c}\mathrm{C} \\
(27.5 \%)\end{array}$ & $\begin{array}{c}\mathrm{D} \\
(30 \%)\end{array}$ & $\begin{array}{c}\mathrm{E} \\
(32,5 \%)\end{array}$ & $\begin{array}{c}\mathrm{F} \\
(35 \%)\end{array}$ \\
\hline Pb content (ppm) & 1.78 & 0.71 & 0.63 & 0.54 & 0.47 & 0.43 \\
\hline Vinegar & $\mathrm{A}$ & $\mathrm{B}$ & $\mathrm{C}$ & $\mathrm{D}$ & $\mathrm{E}$ & $\mathrm{F}$ \\
$(\mathrm{k} \%)$ & $(7,5 \%)$ & $(10 \%)$ & $(12,5 \%)$ & $(15 \%)$ \\
\hline Pb content (ppm) & 1.69 & 1.13 & 0.93 & 0.77 & 0.73 & 0.60 \\
\hline
\end{tabular}

Source: Result of analysis 
Table 3. Long immersion in some solution

\begin{tabular}{|c|c|c|c|c|c|c|}
\hline $\mathrm{Na}_{2}$ EDTA Solution & $\begin{array}{c}\text { A } \\
\text { (kontrol) }\end{array}$ & $\begin{array}{c}\text { B } \\
(60 \\
\text { menit }) \\
\end{array}$ & $\begin{array}{c}\text { C } \\
(65 \\
\text { menit }) \\
\end{array}$ & $\begin{array}{c}\text { D } \\
(70 \\
\text { menit })\end{array}$ & $\begin{array}{c}\mathrm{E} \\
(75 \\
\text { menit) }\end{array}$ & $\begin{array}{c}\mathrm{F} \\
(80 \\
\text { menit })\end{array}$ \\
\hline $\mathrm{Pb}$ content (ppm) & 0.77 & 0.62 & 0.56 & 0.45 & 0.39 & 0.37 \\
\hline Lime Solution & $\begin{array}{c}\text { A } \\
\text { (kontrol) }\end{array}$ & $\begin{array}{c}\text { B } \\
(120 \\
\text { menit }) \\
\end{array}$ & $\begin{array}{c}\mathrm{C} \\
(150 \\
\text { menit }) \\
\end{array}$ & $\begin{array}{c}\mathrm{D} \\
(180 \\
\text { menit }) \\
\end{array}$ & $\begin{array}{c}\mathrm{E} \\
(210 \\
\text { menit })\end{array}$ & $\begin{array}{c}\mathrm{F} \\
(240 \\
\text { menit }) \\
\end{array}$ \\
\hline Pb content (ppm) & 1.78 & 0.49 & 0.42 & 0.38 & 0.31 & 0.27 \\
\hline Vinegar & $\begin{array}{c}\text { A } \\
\text { (kontrol) }\end{array}$ & $\begin{array}{c}\text { B } \\
(15 \\
\text { menit }) \\
\end{array}$ & $\begin{array}{c}\mathrm{C} \\
(30 \\
\text { menit}) \\
\end{array}$ & $\begin{array}{c}\mathrm{D} \\
(45 \\
\text { menit }) \\
\end{array}$ & $\begin{array}{c}\mathrm{E} \\
(60 \\
\text { menit}) \\
\end{array}$ & $\begin{array}{c}F \\
(75 \\
\text { menit) } \\
\end{array}$ \\
\hline Pb content (ppm) & 1.78 & 0.98 & 0.69 & 0.60 & 048 & 0.42 \\
\hline
\end{tabular}

Source: Result of analysis

The results showed that the solution of the chelating agent $\mathrm{Na}_{2}$ EDTA is the most effective and efficient in reducing the content of lead in A. marina fruit. Table 2 and Table 3 show that the concentration of $\mathrm{Na}_{2}$ EDTA $1.3 \%$ with a combination of long soaking 70 minutes $A$. marina fruit produces flour with lead content below $0.5 \mathrm{mg} \mathrm{kg}^{-1}$. These results meet the standard of quality of flour as food.

Mangrove fruit flour is an alternative source of carbohydrates (Table 4). The content of carbohydrates in the flour with a moisture content of $4 \%$ during the study averaged more than $85 \%$. Other supporting factors are important to determine the feasibility of flour A. marina fruit that can be consumed is HCN levels, levels of alkaloids, saponins and levels of tannin levels for these compounds is the taste of a bitter and disliked by consumers as food. Soaking with a solution of lemon juice and vinegar solution can also reduce levels of HCN and tannin.

Table 4. Chemical contents of A. marina fruits

\begin{tabular}{|c|l|c|}
\hline No. & \multicolumn{1}{|c|}{ Parameter } & Contents \\
\hline 1. & Protein content (\%) & 3.90 \\
\hline 2. & Fat content (\%) & 1.80 \\
\hline 3. & Water content (\%) & 34.88 \\
\hline 4. & Ash content (\%) & 1.32 \\
\hline 5. & Karbohidrat content (\%) & 5082 \\
\hline 6. & Tannin content (ppm) & 689 \\
\hline 7. & HCN content (ppm) & 8.37 \\
\hline 8. & Pb content (ppm) & 150 \\
\hline
\end{tabular}

Source: Result of research analysis 


\section{Conclusion}

$\mathrm{Na}_{2}$ EDTA solution and a solution of lime used for fruit maceration Avicennia marina was found to reduce Lead $(\mathrm{Pb})$. Maceration with $1.3 \% \mathrm{Na}_{2}$ EDTA solution for 70 minutes to produce flour Avicennia marina fruit $0.45 \mathrm{ppm}$. Maceration with a solution of lemon juice and vinegar, respectively, and the concentration for 120 minutes and 60 minutes to produce flour Avicennia marina fruit $0.49 \mathrm{ppm}$ and $0.48 \mathrm{ppm}$.

\section{Acknowledgment}

Many thanks for Prof. Dr. Ir. Eddy Suprayitno for their support and care during the research.

\section{References}

Amin, B. (2001). Accumulation of Heavy Metals Pb and Cu In Mangrove (Avicennia marina) in the Coastal Waters of Dumai, Riau. Marine Chemistry Laboratory. Faperika, University of Riau. Riau

Arisandi, P. (2001). Mangrove Type Avicennia marina Alternative Heavy Metal Pollution Control Coastal. http://www.terranet.or.id, accessed January 14, 2006.

Bengen, D.G. (2003). Recognition and Management of Mangrove Systems. Center of Coastal and Marine Resources Studies, Bogor Agricultural University. Bogor.

Gozomora. (2009). Mengenal Pb dan Uji $\mathrm{Na}_{2}$ EDTA. http:/www.twitter.com. Retrieved July 27, 2009.

Hamzah, F., \& Setiawan, A. (2010). Accumulation of Heavy Metals Pb, Cu and Zn in Muara Angke Mangrove Forest, North Jakarta. Journal of Tropical Marine Science and Technology, 2, 2, 41-52.

Imaduddin, Saiful, \& Soedjajadi Keman. (2000). Ability Acetic Acid Solution 25\% on Heavy Metal Content of $\mathrm{Pb}$ reduction in Meat Milkfish (Chanos Chanos forsk), Forum of Community Health Sciences, XIX, 18, 1 33-39.

Lihan, T., Ismail, N, Mustapha, M.A., \& Rahim, S.A. (2006). Content of Heavy Metals In Seafood and levels of uptake By Population In cape Coral, Selangor. The Malaysian Journal of Analytical Sciences, 10.2.

Pararaja, A. (2009). Mengenal Logam Berat (Heavy Metal). http://www.terranet.or.id, accessed January 14, 2009

Pramudji. (2001). Dynamics of Mangrove Forest Area in the Gulf Coast Region Kotania, West Seram. Oseana, 26(3), 44-46.

Sethpakdee, R. (1992). Citrus aurantifolia (Christm. \& Panzer) Swingle. In Coronel, R.E. \& Verheij, E.W.M. (Eds.): Plant Resources of South-East Asia. No. 2: Edible fruits and nuts. Prosea Foundation, Bogor, Indonesia. pp. 126-128.

Shimoda, Y., Ogisu, M., Iwata, S., \& Tajima, T. (1985). Chemical composition of mangroves. 11. Gifu Daigaku Nogakubu Kenkyu Hokoku, 50.155-165 
Sinex, A.S. (2007). EDTA - A Molecule With A Complex Story. Prince George's Community College. http://www.chm.bris.ac.uk/motm/edta/edtah.htm. Accessed on August 1.

Sudarmaji, S., Haryono, B., \& Suhadi. (2003). Analysis of Food and Agriculture. Publisher Liberty Yogyakarta Collaborate with Inter-University Food and Nutrition University of Gajah Mada. Yogyakarta 